\title{
The Growing Pains of Digital Art History: Issues for the Study of Art Using Computational Methods
}

Amanda Wasielewski

Over the past few decades, a series of "questionnaires" in the art journal October has provided a snapshot of new and contentious critical frameworks in art history. ${ }^{.}$While these questionnaires contain their own selection biases, ${ }^{2}$ the editorial impulse to take the temperature of trends in both scholarly and artistic circles has nevertheless provided a useful guide to some of the major concerns in the field in recent years. The second questionnaire to be published by the journal-and the first to be called a "questionnaire" - was on visual culture, a term that aims to expand the notion of art history beyond professionalized artistic practice into the realm of visual artifacts produced outside traditional art contexts, for example popular film, television, advertising, and other cultural ephemera that might have a visual component. October's visual culture questionnaire (I996) was preceded by "Questions of Feminism" (I995) and followed by

I Previous issues saw "conversations" and "interviews" but the first issue to contain responses to a questionnaire posed by the journal was on the topic of feminism in I995: "Questions of Feminism: 25 Responses," October 7I (I995): 5-48. The first so-called "questionnaire" appeared the following year in I996: "Visual Culture Questionnaire," October 77 (I996): $25-70$.

2 This bias stems from the fact that the journal itself is a historical object and embodies the methodology of a particular period in art history. It was founded in 1976 by Rosalind Krauss and Anette Michaelson as a venue for poststructuralist thought in the English-speaking academe.

How to cite this book chapter:

Wasielewski, Amanda. "The Growing Pains of Digital Art History: Issues for the Study of Art Using Computational Methods." In Digital Human Sciences: New Objects-New Approaches, edited by Sonya Petersson, I27-I 5 I. Stockholm: Stockholm University Press, 202 I. DOI: https://doi .org/ı0.16993/bbk.f. License: CC-BY. 
questionnaires on "obsolescence" in artistic practice (2002), the Iraq War (2008), "the Contemporary" (2009), Occupy Wall Street (20I2), "materialisms" (20I6), monuments (20I8), and-most recently-decolonization (2020). ${ }^{3}$ This list contains both questionnaires that deal with contemporary political issues as well as issues around theory and methodology.

The impact of digital culture has become an urgent question in the fields of art and art history. In artistic practice, "post-internet" art has gained a foothold in commercial galleries, and there is increased administrative pressure in universities to incorporate digital humanities methodologies into traditional humanities programs. " "Digital art history" (DAH) is typically defined as art historical research that uses computational methodologies. ${ }^{5}$ Unlike humanities disciplines that deal primarily with analysis of text, art history deals with objects and images. This means that the art historical "data" is more complicated to process and runs aground

3 George Baker, ed., "Artist Questionnaire: 2I Responses," October I00 (2002): 6-97; Benjamin H. D. Buchloh and Rachel Churner, eds., "Questionnaire: In What Ways Have Artists, Academics, and Cultural Institutions Responded to the U.S.-Led Invasion and Occupation of Iraq?" October I 23 (2008): 3-I 84; Hal Foster, ed., "Questionnaire on 'The Contemporary," October I 30 (2009): 3-I 24; David Joselit and Carrie Lambert-Beatty, eds., "[ 5 Responses to a Questionnaire on Occupy Wall Street]," October I42 (20I2): 26-73; David Joselit, Carrie LambertBeatty, and Hal Foster, eds., "A Questionnaire on Materialisms," October I 55 (Winter 20I6): 3-I IO; Leah Dickerman et al., eds., "A Questionnaire on Monuments," October I65 (August I, 20I 8): 3-I77; Huey Copeland et al., "A Questionnaire on Decolonization," October I74 (December I, 2020): 3-I 25 .

${ }^{4}$ It should be noted that an important element of the digital humanities sector is focused on pedagogical tools, which will not be addressed in this essay.

"Matthew K. Gold uses the term "algorithmic" instead of computational, while other scholars use the term "computational." For my purposes, the latter term is more all-encompassing and will be my preferred terminology. For use of these terms see Matthew K. Gold, ed., Debates in the Digital Humanities (Minneapolis, MN: University of Minnesota Press, 20I2); Susan Schreibman, Raymond George Siemens, and John Unsworth, eds., A Companion to Digital Humanities (Malden, MA: Blackwell Publishing, 2004); Anne Burdick et al., Digital_Humanities (Cambridge: MIT Press, 20I2); Melissa M. Terras, Julianne Nyhan, and Edward Vanhoutte, eds., Defining Digital Humanities: A Reader (London: Routledge, 2016). 
against complex questions of beauty and aesthetic experience that have haunted the field since its inception. These special issues therefore necessitate a separate discussion of digital humanities methodologies in art history under the rubric of digital art history.

Computational methodologies in art history typically entail quasi-quantitative approaches for studying artists and artwork including image recognition, network analysis, data mining, machine learning, mapping, visualization, and digital reconstruction. ${ }^{6}$ In all of these methods, computer software is used to process a set of data, whether that is images, text, dates, locations, or any other metric. In some cases, the term digital art history has also been used as a term for the study of digital art (that is, art made in digital media) or a catch all term for both the study of digital art and the use of digital methods.

Given the ongoing debates around digital methodologies and the centrality of text and image databases for contemporary scholarly work, why has October not done a questionnaire on "digital art history"? While the "materialisms" questionnaire circled around post-internet art (in the context of a "materialist turn"), 7 questions of methodology and digitization have gone largely unremarked in mainstream art history scholarship. ${ }^{8} \mathrm{Up}$ until now, it has primarily been left to art institutions (that is,

${ }^{6}$ Quasi-quantitative methods would perhaps make up the bulk of the data used in digital humanities methodologies. I would define quasi-quantitative data as any numerical data that comes from qualitative interpretation. Humanities scholarship, by definition, is primarily concerned with qualitative data points.

7 "Post-internet" is a term coined by Marisa Olson in 2008 to describe artistic practices that come out of a society where the internet is omnipresent. Olson says, "I think it's important to address the impacts of the internet on culture at large, and this can be done well on networks but can and should also exist offline." The fact that the art world has largely ignored digital, internet, and computer art until it had material manifestations (or implications for new materialisms) is remarkable insofar as dematerialization has long been a key facet of digital art (despite the impossibility of true dematerialization). Régine Debatty, "Interview with Marisa Olson," We Make Money Not Art (blog), March 28, 2008, http://we-make-money-not-art.com/how_does_one_become_marisa; Artie Vierkant, “The Image Object Post-Internet,” Jstchillin (blog), 2010, http://jstchillin.org/artie/pdf/The_Image_Object_Post-Internet_a4.pdf.

8 Joselit, Lambert-Beatty, and Foster, "A Questionnaire on Materialisms.” 
archivists, librarians, curators, et cetera) and non-art historians to address the study of art and visual culture via computational methodologies. Attempts by non-art historians, in particular, to study art in this way has hindered acceptance of these methodologies as legitimate tools for art historical scholarship. ${ }^{9}$ While scholars such as Harald Klinke, a founding editor of the Journal of Digital Art History, often claims that DAH is transforming the discipline of art history at large, there is scant evidence of this in mainstream art history journals. ${ }^{\mathrm{IO}}$

Art history is a conservative discipline that, more than most areas of study in the humanities, continues to police its boundaries in both subject matter and methodology. ${ }^{\text {II }}$ Keeping a critical outlook is certainly important for scholars of new technology, given the pervasiveness of Silicon Valley's techno-utopian ideology, but completely ignoring its political, cultural, and societal impact is an untenable position for art history scholarship. ${ }^{12}$ It is certainly time for art history to reckon with "the digital" as more than a subfield or a medium. This chapter aims to interrogate how we might begin to look at "digital art history" from within the field and how digital methods of art history scholarship square with digital (and postdigital) practices of artists.

9 The work of a computer scientist at Rutgers University, Dr. Ahmed Elgammal, is an example of one such project, run by non-art historians, that would benefit from a deeper knowledge of the discipline. This is the type of project that Claire Bishop focuses her critique on in "Against Digital Art History." "Digital Humanities Laboratory at Rutgers," https://sites.google.com/site/digihumanlab/home; Claire Bishop, "Against Digital Art History," International Journal for Digital Art History, no. 3 (July 27, 20I 8): I 22-I3I.

ro See Harald Klinke, "The Digital Transformation of Art History," in The Routledge Companion to Digital Humanities and Art History, ed. Kathryn Brown (New York: Routledge, 2020), 32-42; Harald Klinke, "Big Image Data within the Big Picture of Art History," International Journal for Digital Art History, no. 2 (October I8, 2016): I4-37; Anna Dahlgren and Amanda Wasielewski, "The Digital U-Turn in Art History." Submitted.

I Klinke affirms this widely held view but argues against it in "The Digital Transformation of Art History," 33.

I2 One has only to read mainstream media studies scholarship on internet culture, the gig economy, and other topics to see that interest in new technology by no means signals lack of criticality. 
Interest in the digital humanities and digital art history is often confined to nonmodern, noncontemporary, and non-Western specialties. It is somewhat ironic that ancient and medieval art-the oldest art we study-seems to lend itself to digital humanities methodologies, whereas scholars of modern and contemporary art largely ignore such techniques (with the notable exception of scholars of photography and film). There are many possible explanations for this, including the availability of data and the clear delineation of the art world and artistic practice in modern times. However, now that there have been some 50 years of artwork created with the aid of software and computer technology, digital methodologies can also be tested on objects within their own structural paradigm. How might the terms of engagement shift when digital methods are used to study born-digital works of art versus artwork created with predigital materials? Despite the methodological fundamentalism of individual scholarly inquiry, different methodologies-including the computational-have a role to play in understanding both preand postdigital artistic practice.

\section{Learning from the Visual Culture Debate}

Looking back at October's "visual culture" questionnaire from I996, it seems that many of the respondents were wringing their hands over nothing - at least, nothing as serious as they make it out to be. The study of visual culture has been folded into art history departments without the destruction and dismantlement that scholars seemed to fear in the mid-'9os. Much like computational methodologies today, visual culture studies are popular with historians of photography, medievalists, and specialists in non-Western art. This is hardly surprising, as these specialties were some of the latest additions to the discipline and, so, perhaps the less attached to canonical/exclusive definitions of art. ${ }^{\mathrm{I} 3}$ Despite the alarm raised

${ }^{13}$ Photography, medieval art, and non-Western art were, for example, not considered part of the discipline of art history until the 2oth century. Contemporary art, too, was not considered part of art history but, rather, art criticism. The reasons for this are, however, different from the reasons for the exclusion of those other specialties. 
in the pages of October, scholarship on "visual culture" has not spelled the death of art history, or, indeed, the term "art" itself. Likewise, there is no obsessive preference in art history and visual culture departments for the "visual" over nonvisual artistic practices. ${ }^{\mathrm{I}}$ Given that the internet had recently arrived for a broader public at the time of writing, it follows that some of the writers in the visual culture questionnaire make reference to digital culture- “cyber" culture, in '9os parlance. However, not nearly as many of the respondents comment on the rise of the internet as one would expect given its relevance for the circulation of digital images and videos.

Despite residing somewhat outside of the discipline of art history herself, Susan Buck-Morss takes a conservative position with regard to the implications of visual culture for the category of "art." ${ }^{5}$ Her thoughts on the topic are numerous and complex and are, in fact, inadequately conveyed in the short text for the questionnaire. However, her response is notable in that she is one of the few scholars to refer to digital culture, albeit in a dismissive way. She writes:

While the Internet is the topic and the medium for new courses in visual culture, it is striking to anyone who has visited the Internet how visually impoverished a home-page can be. Cyberdigits reproduce the moving image haltingly, and the static image unimpressively. The possibility of computer screens replacing television

${ }^{14}$ This was an issue (i.e., visuality) that was raised in the questionnaire by Jonathan Crary, Thomas Crow, and others. "Visual Culture Questionnaire."

is Buck-Morss's stance toward visual culture studies was tempered in other writing and statements in the years that followed the questionnaire. In 2004, she published a paper praising the political potential of this methodology, writing, "Visual studies can provide the opportunity to engage in a transformation of thought on a general level. Indeed, the very elusiveness of visual studies gives this endeavor the epistemological resiliency necessary to confront a present transformation in existing structures of knowledge, one that is being played out in institutional venues throughout the globe." Susan Buck-Morss, "Visual Studies and Global Imagination," Papers of Surrealism, no. 2 (2004). I would also like to note that in spring 20I4 I took a course titled "Software, Globalization and Political Action" at the CUNY Graduate Center cotaught by Buck-Morss and Lev Manovich. Buck-Morss has clearly revised her early dismissal of digital media. 
screens may mean a great deal to stockholders of telephone companies, but it will not shake the world of the visual image. Aesthetic experience (sensory experience) is not reducible to information. Is it old fashioned to say so? Perhaps the era of images that are more than information is already behind us. Perhaps discussions about visual culture as a field have come too late. ${ }^{16}$

The most striking part of this excerpt is the claim that "aesthetic experience (sensory experience) is not reducible to information." Most generous definitions of the term information would allow it its broad etymological origins as idea, concept, or form of knowledge. ${ }^{17}$ A strict Kantian reading of aesthetics would indeed separate sensory experience from mere concept, but in the passage above the term "information" is a convenient straw man. ${ }^{18}$ BuckMorss conflates aesthetic experience with images themselves, neither of which she wishes to be merely "information"-but who ever said that they were? ${ }^{19}$ Art history sets itself to the task of interpretation and understanding art and so, inevitably, deals with concepts, but no one is arguing that an artwork is reducible merely to the concepts attendant to it.

We need to continually demystify terminology like "information," "data," and "digital" in the humanities. These terms are not obscure loan words from computer science but, rather, concepts that apply to all kind of contemporary scholarship. Although contemporary technological terminology may seem foreign to those steeped in the traditional language of art history, all of the

I6 Susan Buck-Morss, "Visual Culture Questionnaire," October 77 (I996): 30 .

17 “Information, n.," in OED Online (Oxford University Press), http:// www.oed.com/view/Entry/95568.

I8 Immanuel Kant, Critique of Judgement, ed. Nicholas Walker, trans. James Creed Meredith (Oxford: Oxford University Press, 2007), 42-43 $(\mathbb{S} 6-9)$.

19 Buck-Morss expanded her thoughts on Kantian aesthetics in relation to contemporary art in an interview with Grant Kester from I997. Following the thinking of Walter Benjamin, she considers "art" a category to be dead. She labels certain contemporary artwork the "Piss and Shit School" and declares identity politics a "cul-de-sac." Grant H. Kester, "Aesthetics after the End of Art: An Interview with Susan Buck-Morss," Art Journal 56, no. I (I997): $38-45$. 
concepts floated in digital art history are the same as those that have been floated in art history proper under different auspices.

Some of the most fruitful applications of digital humanities techniques in art history have been in the realm of artists'/artworks' networks and provenance. As Matthew Lincoln argues, an interest in describing or charting networks is already "implicit" within many nondigital research practices across the discipline. ${ }^{20}$ However, computational studies of networks are still mostly published in specialist digital art history journals or scientific journals rather than traditional art history journals. ${ }^{2 \mathrm{I}}$ One study, by Samuel P. Fraiberger et al. and published in Science, looks at quantitative network relationships between museums, exhibitions, auction prices, and artists. They found that, if artists had access to prestigious institutions located at the center of many networks early in their career, they typically had access to those same institutions their entire careers. Artists at the periphery of networks had a higher rate of dropping out. ${ }^{22}$ While this may come as no surprise to art historians-that artists with the "best" networks are more likely to succeed-studies like these add nuance and weight to art world truisms regarding artists' relationship to the market, capital, success, and status. This kind of study need not be an end in itself. As Benjamin Zweig argues, this type of study might qualify as "results" but it does not provide "answers" (that is, arguments), and that is where other methodologies and theory can come into play. ${ }^{23}$ Writing specifically on methods of digital mapping, Béatrice Joyeaux-Prunel writes, "Mapping is a research process rather than an outcome.” ${ }^{24}$ DAH critic Claire Bishop writes

${ }^{20}$ Matthew D. Lincoln, "Tangled Metaphors: Network Thinking and Network Analysis in the History of Art," in The Routledge Companion to Digital Humanities and Art History, ed. Kathryn Brown (New York: Routledge, 2020), 73 .

${ }^{21}$ A number of examples are cited in Lincoln, "Tangled Metaphors."

22 Samuel P. Fraiberger et al., "Quantifying Reputation and Success in Art," Science 362, no. 64I6 (November I6, 2018): 825-829.

${ }_{23}$ Benjamin Zweig, "Defining Digital Art History: What It Is, Is Not, and Should Be," paper presented at the Digital Humanities Seminar, Uppsala University (September 25, 2019).

${ }^{24}$ Béatrice Joyeaux-Prunel, "Digital Humanities for a Spatial, Global, and Social History of Art," in The Routledge Companion to Digital 
that computational methodologies are "boring and formulaic," but the results of computational methodologies need not be an end in themselves. ${ }^{25}$

One of the often-cited examples of a successful application of data analysis in art history is the network diagram MoMA created for their exhibition Inventing Abstraction I9IO-I925 (December 23, 20I 2-April I 5, 20I3). ${ }^{26}$ This network map was designed with another famous chart in mind. In I936, the first director of MoMA, Alfred H. Barr Jr., created a diagram to accompany the exhibition Cubism and Abstract Art. It depicts the networks of influence that led to the development of "nongeometrical abstract art" and "geometrical abstract art" in Europe and the United States. ${ }^{27}$ The neat modernist progression of such a diagram, which purports to trace the evolution of Western art from the late I9th century to the contemporary, is rife with dei ex machina in the form of non-Western art ("Japanese prints," "Near Eastern Art," and "Negro Sculpture") and the technological development of the time period ("Machine Esthetic"). These static and isolated "helpers" propel the development of Western art in Barr's diagram.

Humanities and Art History, ed. Kathryn Brown (New York: Routledge, 2020), 94 .

${ }_{25}$ Johanna Drucker and Claire Bishop, "A Conversation on Digital Art History," in Debates in the Digital Humanities 2019 (Minneapolis, MN: University of Minnesota Press, 20I9), https://dhdebates.gc.cuny.edu/read /untitled-f2acf72c-a469-49d8-be35-67f9acie3a6o/section/3aedfd 2c-28of-4029-b3fi-3egai i 794coi \#ch27.

${ }^{26}$ Nancy Ross, "Teaching Twentieth Century Art History with Gender and Data Visualizations," The Journal of Interactive Technology and Pedagogy, no. 4 (December 2, 2013); Mitchell Whitelaw, "Representing Digital Collections," in Performing Digital: Multiple Perspectives on a Living Archive, eds. David Carlin and Laurene Vaughan (Farnham: Ashgate Publishing, 20I 5), 9I; Lev Manovich, "Data Science and Digital Art History," International Journal for Digital Art History, no. I (June 26, 20I 5): I6; Johanna Drucker et al., "Digital Art History: The American Scene," Perspective: Actualité en histoire de l'art, no. 2 (December 5, 2OI 5): 3; Claire L. Kovacs, "Mapping Paris: Social and Artistic Networks, I8 55-I889," Leonardo 49, no. 5 (March 3 I, 2016): 446; Zweig, "Defining Digital Art History: What It Is, Is Not, and Should Be."

${ }^{27}$ For further discussion of these two diagrams see Alexander Alberro, "A Messier Coherence: Inventing Abstraction at the Museum of Modern Art," Modernism/Modernity 20, no. 2 (June 27, 20I3): 37I-38I. 
The connections that mapped in the 2013 diagram, on the other hand, are based on the number of letters exchanged between the figures in the diagram. ${ }^{28}$ Key nodes of influence in the network are highlighted in red. This provides some predictable results: Pablo Picasso and Vasily Kandinsky are among those most well connected. It also, however, contains some surprises: historically underappreciated female artists Sonia Delaunay-Terk and Natalia Goncharova are also among those most well connected on the chart. In addition to visual artists, the chart includes the likes of Guillaume Apollinaire and Claude Debussy in the network of influences. Network mapping such as this has the potential to bring figures back into the canon. ${ }^{29}$ However, researchers must compile their datasets carefully, as women and minorities may be underrepresented in digitization projects and therefore within existing museum databases. ${ }^{30}$ This means that any analysis merely reproduces existing collection or archival biases.

An issue that often arises in the literature on digital humanities is the relationship between the research question and data analysis. Media theorist Lev Manovich is a proponent of "exploratory data analysis" or "unsupervised learning"-terms borrowed from the field of machine learning. Manovich argues that using such methods means that research questions in the humanities will not be predetermined but will be drawn from the data itself. He writes:

Why should we use computers to classify cultural artifacts, phenomena or activities into a small number of categories? Why not instead use computational methods to question the categories we already have, generate new ones, or create new cultural maps that relate cultural artifacts in original ways? ${ }^{31}$

Although Manovich's stated goal is to do away with existing bias in the categorization of cultural artifacts, this freeform approach

${ }_{28}$ Manovich, "Data Science and Digital Art History," I6.

29 Kathryn Brown and Elspeth Mitchell, "Feminist Digital Art History," in The Routledge Companion to Digital Humanities and Art History, ed. Kathryn Brown (New York: Routledge, 2020), 44.

3० Brown and Mitchell, "Feminist Digital Art History," 46.

${ }^{31}$ Manovich, "Data Science and Digital Art History," 24. 
is built on the assumption that datasets are neutral or comprehensive and that there are objective facts about art held within them. The data itself will reproduce human bias (just as humans would) in the categorization of objects. As recent scholarship on the topic of data bias has shown, this is a huge issue in data collection and analysis, and the belief in the objectivity of big data sets can have dire social consequences. ${ }^{32}$

For humanities scholars who favor a critical theory perspective, the centrality of the argument and authorial voice cannot be discounted. ${ }^{33}$ In an article from 2013, Johanna Drucker points particularly to the influence of "[s]emiotics, structuralism, poststructuralism, psychoanalysis, Marxism, cultural and critical studies, and feminist" methodologies as "profound" for the discipline of art history, a seismic change she does not see (yet) in digital art history. ${ }^{34}$ Bishop draws from Drucker to argue against digital art history on the basis that what Drucker outlines as the future of digital art history amounts to a "combination of digital technologies, network analysis, and connoisseurship." 35 Bishop takes issue with what she perceives as the "fatuity" of digital art history scholarship, where "[b]asic terms like beauty (and even portraiture) remain uninterrogated." ${ }^{6}$ Ultimately Bishop argues that the reliance on and belief in data as revolutionary to the field of art history "perpetuates uncritical assumptions about

${ }^{2}$ Safiya Umoja Noble, Algorithms of Oppression: How Search Engines Reinforce Racism (New York: New York University Press, 20 18); Ricardo Baeza-Yates, "Bias on the Web," Communications of the ACM 6I, no. 6 (June 20I8): 54; Shaozeng Zhang, Bo Zhao, and Jennifer Ventrella, "Towards an Archaeological-Ethnographic Approach to Big Data: Rethinking Data Veracity," Ethnographic Praxis in Industry Conference Proceedings 20I8, no. I (2018): 62-85; Andrew G. Ferguson, The Rise of Big Data Policing: Surveillance, Race, and the Future of Law Enforcement (New York: New York University Press, 20I7); Megan Garcia, "Racist in the Machine: The Disturbing Implications of Algorithmic Bias," World Policy Journal 33, no. 4 (2016): I I I-I I7.

33 Michelle Millar Fisher and Anne Swartz, "Why Digital Art History?" Visual Resources 30, no. 2 (April 3, 20I4): I3I.

34 Johanna Drucker, “Is There a 'Digital' Art History?” Visual Resources 29, no. I-2 (June I, 20I3): 5 .

35 Claire Bishop, “Against Digital Art History," International Journal for Digital Art History, no. 3 (July 27, 2018): I 23.

${ }^{6}$ Bishop, “Against Digital Art History,” I 24. 
the intrinsic value of statistics" and feeds a neoliberal system. ${ }^{37}$ While this may be true in some cases, computation analysis of networks can also expose some of the more insidious ways markets have driven art's valuation and propped up certain artists. As long as a thoughtful mix of art historical methodologies are utilized, which recognize the politics and problematics of terminology and the discipline's historicity, adding digital tools to the mix need not produce fatuous or neoliberal work.

Drucker and Bishop subsequently debated some of these points directly in an email exchange published in the 2019 edition of Debates in the Digital Humanities. Countering the accusation that digital humanities methodologies are somehow more complicit with neoliberalism than traditional methods, Drucker writes, “This is patently false. It also suggests that a 'pure' humanities exists that is untainted: the humanities of work that embraces social good and the highest virtues of humankind without complicity in the institutional frameworks that support it." ${ }^{8}$ Bishop's point, however, that the university's focus on digital humanities research as a reflection of neoliberal values imposed on otherwise unquantifiable humanities research still stands.

Some of the most controversial and problematic digital art historical research concerns studies of digital images and image compositing/creation through machine learning. As Bishop points out, analysis of large groups of image data often ignores and erases too much context for it to be meaningful. That is not to say it could not be done with an eye to these issues but that, as of yet, too many examples of image analysis are superficial, and the results of such research risk being inconsequential to art's history. For example, a 2019 commercial gallery show in New York was advertised as a "collaboration" between a computer scientist and an AI system to create new art out of a repository of old masters portrait imagery, but, as journalist Ian Bogost points out, the subject

37 Bishop, “Against Digital Art History," I 25.

${ }^{8}$ Johanna Drucker and Claire Bishop, "A Conversation on Digital Art History," in Debates in the Digital Humanities 2019 (Minneapolis, MN: University of Minnesota Press, 20I9), https://dhdebates.gc.cuny.edu/read /untitled-f 2 acf 72 -a $469-49$ d 8-be3 5-67f9acre3a 6o/section/3aedfd $2 \mathrm{c}$ -28of-4029-b3fi-3egai I794coi\#ch27. 
of the portraits used and the specificity of their time/place is completely erased in such an exercise. ${ }^{39}$ The project assumes that the value of old masters' work has nothing to do with its specificity and everything to do with its superficial features. While such visual analyses of digital images might be linked with the dates of creation for the images in question, dates alone are not enough to construct history. Drucker also points to some of the issues surrounding the use of digital images to collect "data" on the object depicted, writing, "[a]s previously noted, digital objects are fully remediated. They exist in the fungible condition of code. The way artifacts are encoded depends on the parameters set for scanning and photography." ${ }^{\circ}$ The layers of mediation in both metadata and encoding practices cannot be discounted in any study that employs digital humanities methodologies.

\section{Studying Internet Art}

Like digital art history, digital art (computer art, internet art, et cetera) has long been ghettoized under the category of new media art. During the early stages of a recently completed research project, I met with Lev Manovich to discuss how digital methods might be applied to my study of early internet art. ${ }^{4{ }^{\mathrm{I}}} \mathrm{He}$ suggested text mining the $<$ nettime $>$ mailing list, ${ }^{42}$ one of the key forums for internet art and theory in the '9os. Since <nettime> is archived online, I would be able to do different kinds of textual analysis of the bulk of the content there. In the end, however, I decided to focus my project on an earlier period leading up to the advent of the internet in the Netherlands within a community of urban squatters, hackers, activists, and artists. As such, my methodology turned out to include the decidedly analog techniques of archival research and oral histories.

39 Ian Bogost, “The AI-Art Gold Rush Is Here," The Atlantic, March 6, 20I 9, https://www.theatlantic.com/technology/archive/2019/03/ai-created -art-invades-chelsea-gallery-scene/584I34.

$4^{\circ}$ Drucker, "Is There a 'Digital' Art History?" 8.

${ }^{4}$ Amanda Wasielewski, From City Space to Cyberspace: Art, Squatting, and Internet Culture in the Netherlands. Amsterdam University Press. Forthcoming.

42 “<nettime> Mailing List Archive," https://nettime.org/. 
As with the selection of any methodology, a researcher needs to interrogate what they hope to learn by using it, which does not necessarily have to be a concrete outcome. It goes without saying that, even when a researcher constructs an explicit plan for a piece of humanities research, an argument can turn out slightly or even vastly different from how they thought it would. Any methodological decision will yield a different kind of output and, despite the warring camps within any discipline, this does not mean that one is "right" and another is "wrong." Though it seems simple to point out these things about choosing a methodology, a version of which is taught in art history departments across the world, it is useful to be reminded of it. Even as a senior scholar-perhaps especially as a senior scholar who has become known for working in a certain way within a certain framework of analysis-it is useful to think of methodologies as techniques that can be combined and mixed together rather than camps ready to wage war on one another. This also applies to political and ideological methodologies: intersectionality would never have been born if gender, race, postcolonial, and Marxist theory had never been brought together. Digital art history or computational methodologies are not a threat to art history any more than visual culture studies were. Nor are they useless and unfit for the study of art.

Returning to the example of internet art, it is clear that there are questions that might be answered by doing a computational analysis of the <nettime> mailing list. In the early to mid-'9os, there was a network of artists (many of whom were from former Soviet countries) who created art that was meant to be viewed in an internet browser window. Theorists and artists from both the Netherlands and Germany interacted with these artists on $<$ nettime $>$ and in other venues, namely in-person conferences and events. One could perhaps devise a network analysis or even a geographical map of <nettime $>$ participants based on which figures responded to and interacted with each other. Key phrases and topics could be pinpointed or often-cited artists or theorists might be uncovered. This is, of course, just one set of data that does not encapsulate the entirety of the discourse, but that does not mean it cannot be usefully analyzed with computational methodologies. Before demonstrating what can be done with a given set of data, 
however, one has to ask why it should be done in the first place. Every piece of research starts from a clue, whether that is an errant observation, a hunch, or the existence of a set of data. It should be quite obvious that the demonstration of a technique-digital or otherwise-falls under the category of pedagogy rather than scholarly argument. That is not to say that pedagogy is a less valid pursuit for scholars, but pedagogical demonstration and argument are so often confused with each other in debates on digital art history that it seems necessary to make that distinction explicit.

Despite the availability of this already-digitized database, which is often not the case for older periods of artistic production, it may not hold the answers a researcher finds interesting or important to highlight. As it turns out, none of the questions that can be drawn from the <nettime $>$ mailing list were ones that were relevant to the research I conducted, but that does not mean that they might not be in future research on the same topic. Critics and scholars have approached internet art with a variety of other methodologies that I have found more or less useful. For example, some of the earliest attempts to bring internet art into the fold of art historical scholarship applied Greenbergian formalism to the work, which is still a dominant thread in writing on this period. ${ }^{43}$ This type of analysis was less interesting to me than, for example, the economic and political framework that scholars like Julian Stallabrass have explored. ${ }^{4}$

The difference between utilizing digital humanities methodologies on older artforms and researching internet art, as well as

43 Clement Greenberg was an American art critic who devised a theory of art where work was judged based on its truth to its medium, or "medium specificity." Internet art critics have picked up on the idea that there are certain qualities of the "medium" of internet art that are unique and that the best work highlights these attributes. Some of Rosalind Krauss's ideas on art follow Greenberg and are also highlighted by writing on internet art. See Tilman Baumgärtel, Net.art: Materialien zur Netzkunst (Nuremberg: Verlag für Moderne Kunst, I999); Tilman Baumgärtel, Net.art 2.0: New Materials Towards Net Art (Nuremberg: Verlag für Moderne Kunst, 200I); Josephine Bosma, Nettitudes: Let's Talk Net Art (Amsterdam: Institute of Network Cultures, 20I I).

44 Julian Stallabrass, Internet Art: The Online Clash of Culture and Commerce (London: Tate Publishing, 2003). 
other born-digital works, is that digital works were created in the same systemic paradigm that computational methodologies utilize. I would not wish to overstate the importance of this, but it undoubtedly creates opportunities that pairing analog works with digital methods does not.

\section{Just Another Archive?}

The extent to which the minutia of our everyday life exists as data on computers, phones, or in server farms (the "cloud") is unprecedented. Blockbuster data security revelations like the Facebook/ Cambridge Analytica scandal of 2018, as well as the Edward Snowden disclosures of 2012 , have brought some of the issues of data privacy and personal data ownership to the surface in political discourse. While there are certainly sinister and undesirable implications of this kind of mass data collection and surveillance, there is also a potential wealth of information that could be available to historians (after accounting for any ethical issues of using it, of course). If an artist creates their work on a computer, the process through which they made the work is often documented in more detail than ever before.

An interesting example of how this has been used in scholarship is Doug Reside's research on the musical RENT. Reside was appointed as the first digital curator at the New York Public Library's Performing Arts division, where he has written about and experimented with digital humanities methodologies. After learning that the Library of Congress had i 80 floppy disks from RENT creator Jonathan Larson, who died from a heart condition at the age of thirty-five in I996, Reside set about analyzing the music and text files contained on the disks. ${ }^{45}$ Not only was Reside able to pinpoint sections of the RENT libretto that had been edited but he was also able to see previous and even deleted versions of the text. Additionally, he was able to investigate the notes that Larson took on various books he read as well as the exact moment he created or edited certain files. This type of archive is

45 Doug Reside, “Last Modified January I996: The Digital History of RENT," Theatre Survey 52, no. 2 (November 20I I): 335-340. 
really no different from any paper archive except that it contains such down-to-the-second details. It is an archive on steroids.

Artists themselves have been quick to explore the poetic potential of digital traces. Bishop cites Walid Raad's use of data and visualization in his work Scratching on Things I Could Disavow (ongoing). ${ }^{46}$ The work reflects on the nature of globalized networks and the concept of researching the relationship between art institutions and economic and political power in the Arab world. Bishop states that the work is "at first glance very $\mathrm{DH}$ [digital humanities]," a statement that still somehow treats "the digital" as a separate field, something apart, rather than something inextricably entwined in every part of social, economic, and political life today.

Another example of this sort of exploration of data in artistic practice is Forensic Architecture's digital reconstructions and models of instances of political violence. Without readily accessible trails of data, the projects of Forensic Architecture would not be possible. Their most well-known work, Triple-Chaser, documents the way in which tear gas cannisters made by a company called Safariland were used on the US-Mexico border against migrants. The work was inspired by the controversy surrounding the owner of Safariland, Warren B. Kanders, who was a board member of the Whitney Museum of American Art. The connection between the Whitney and Kanders demonstrated the extent to which the moral and ethical position of the artists whose work is on display in the museum is disregarded in order to flatter wealthy donors such as Kanders. After Forensic Architecture were invited to participate in the 2019 Whitney Biennial, they decided to investigate and recreate this story, training “'computer vision' classifiers to detect Safariland tear gas canisters among the millions of images shared online." ${ }^{47}$ Kanders eventually resigned under the pressure of protests against his continued position at the museum.

These projects demonstrate that data and the use of data need not be dull. Is it so unfathomable that art historical research could also explore some of the poetic potential of artworks' data? That

${ }^{46}$ Drucker and Bishop, "A Conversation on Digital Art History."

47 Forensic Architecture, "Triple-Chaser: Forensic Architecture," https:// forensic-architecture.org//investigation/triple-chaser. 
insights collected from large repositories of data could feed into a compelling argument about works of art? As with any other methodology, the interesting part of a piece of research in digital art history is inevitably what it has to say about a work of art, an artist, or a moment of artistic creation.

In the cases above, both artistic and scholarly, the researchers in question were dealing with readily available large datasets. Doug Reside's research is perhaps a glimpse into the future, when archival work will have to contend with personal data. Perhaps when every artist any art historian wants to study has a hard drive full of working files, correspondence, and notes, computational methodologies to sort and unpack the massive amounts of data will start to seem more relevant. Visualizations like those created by artists like Walid Raad and Forensic Architecture could eventually be useful in telling the story of complex sets of images and complicating the basis upon which they were collected.

\section{The Problem of Data}

The main hindrance for art historical uptake of computational methodologies is not primarily that they are boring or neoliber$\mathrm{al}$; it is that preexisting datasets for art history are often flawed, biased, or incomplete. For noncanonical or niche projects, datasets rarely exist and almost always need to be created first before they are analyzed. More generalized analyses using existing datasets, on the other hand, are often working with flawed or biased data. The generalized art datasets that already exist tend to be composed of primarily Western, canonical painting. Part of the rationale for this is, one would assume, that existing image analysis tools work best on two-dimensional works. There are also copyright issues to contend with for modern and contemporary works. While attempts have been made to unite the various museum collections of images and their attendant metadata, no such comprehensive dataset yet exists. ${ }^{48}$ Even it if did, it would likely

$4^{8}$ Gjorgji Strezoski and Marcel Worring, “OmniArt: A Large-Scale Artistic Benchmark," ACM Transactions on Multimedia Computing, Communications, and Applications I4, no. 4 (October 23, 20I 8): 88:I-88:2I. 
replicate the biases of Western museums, an aspect that would need to be dealt with in any "general" analysis of art.

Indeed, existing art datasets, such as the popular WikiArt dataset, do not meet academic standards for art historical research in that the sources of the information provided is not properly documented. WikiArt includes metadata that is at least partially crowdsourced from the general public, which even researchers in computer science have found problematic as they worked with the dataset. ${ }^{49}$ Most contemporary digital art history projects that might benefit from using computational methodologies need to actually create the data first before studying it. This of course poses a whole host of problems, not least that creating, collecting, managing, and storing data is a very expensive endeavor. Paul Jaskot writes that art history has long been in the business of collecting encyclopedic accumulations of artworks for iconographic analysis and, so, the era of big data collection is nothing new for art history. ${ }^{50}$ These typological and formalist aims, however, are no longer the primary motivation for art historical scholarship. ${ }^{\text {I }}$ For both I9th-century art collections and contemporary datasets, collecting is not a neutral activity. The accumulation of nonWestern artworks and artifacts during the modern era was part of the Western colonialist project, which museums continue to perpetuate. Big data collection today, on the other hand, assumes a comprehensiveness that elides systemic biases.

Looking at the projects that Johanna Drucker cites in her published debate with Claire Bishop as examples of successful digital art history projects, every single one of them required the creation of the data they intended to study. Furthermore, many of them have goals more in line with archaeological research rather than art historical research. She cites projects, such as the Dunhuang Cave Project funded by Getty and UNESCO, which required enormous

49 Ahmed Elgammal et al., "The Shape of Art History in the Eyes of the Machine," January 23, 20I8, http://arxiv.org/abs/I801.07729v2, 5-6.

5o Paul B. Jaskot, "Digital Methods and the Historiography of Art," in The Routledge Companion to Digital Humanities and Art History, ed. Kathryn Brown (New York: Routledge, 2020), 9.

${ }^{5}$ Anna Dahlgren and Amanda Wasielewski, "The Digital U-Turn in Art History." Submitted. 
amounts of image and other data collection, and work on burial mounds that required the development of techniques to begin collecting data on the sites. ${ }^{52}$ Certainly now that, for example, much of the Dunhuang caves are digitized and available to explore in a virtual environment, art historical study of them is much easier. However, this is no different from an art historian searching online archives of medieval manuscripts or other digitized art objects. Drucker also cites the compilation of the Getty Provenance Index, a project that has the primary purpose of creating a complex dataset (not actually developing an argument based on it)..$^{53}$ She goes on to cite a few projects that utilize preexisting textual datasets, which are certainly easier to deal with than image-based data but still require a concerted effort to compile in many cases.

As mentioned, born-digital data may eventually solve some of the issues for studying art via computational methods, but, for now, the major obstacle for meaningfully implementing some of these methodologies in art history is that datasets simply do not exist or are too partial, distorted, or full of noise to really be useful. The solution to this, however, is not necessarily more mass digitization projects. We need to think deeply about the implications of such projects, as there are also myriad political, social, and ethical quandaries involved. ${ }^{54}$

As much as art historians might resist the turn toward digital methods, they will only grow more useful for future generations of scholarship (if both technological progress and the discipline

52 Neville Agnew, ed., Conservation of Ancient Sites on the Silk Road: Proceedings of the Second International Conference on the Conservation of Grotto Sites, Mogao Grottoes, Dunhuang, People's Republic of China, June 28-July 3, 2004 (Los Angeles, CA: Getty Publications, 2010); Melanie A. Riley, Date Automated Detection of Prehistoric Conical Burial Mounds from LIDAR Bare-Earth Digital Elevation Models (Master's thesis, Northwest Missouri State University, 2009); Gunnar Liestøl and Terje Rasmussen, "In the Presence of the Past: A Field Trial Evaluation of a Situated Simulation Design Reconstructing a Viking Burial Scene," in Media Inspirations for Learning: Proceedings of EDEN 20Io, eds. A. Szucs and A.W. Tait (Budapest: Budapest University of Technology, 2010).

53 Getty Research Institute, "ProvenanceIndexDatabases," https:/www.getty .edu/research/tools/provenance/search.html.

54 See Nanna Bonde Thylstrup, The Politics of Mass Digitization (Cambridge: MIT Press, 2019). 
itself continue on in the same vein). The biggest issue right now for digital art history is available data to study, but, before we begin the arduous task of compiling such data, it is worthwhile to think what we might hope to achieve with it. As for the datasets that already exist, it is up to art historians to unlock insights they might hold while maintaining a critical eye toward biases. As Emma Stanford writes, "In attempting to maximize the potential impact of a proposed digitization project, an institution may focus on the 'important' parts of its collection, but importance is an extremely subjective measure dependent on many variables." ${ }_{55}$ Computational methodologies can be relevant, be useful, and lead researchers to interesting avenues of inquiry, but that may only happen if the digital paradigm is no longer ghettoized as a separate field of inquiry. We live and operate as scholars almost completely within digital culture, and, so, we need not subscribe to either methodological fundamentalism or digital ghettoization.

\section{Acknowledgments}

The research for this chapter was conducted within the project Sharing the Visual Heritage (metadataculture.se) at Stockholm University. It was made possible through the generous support of the Swedish Research Council.

\section{References}

Agnew, Neville, ed. Conservation of Ancient Sites on the Silk Road: Proceedings of the Second International Conference on the Conservation of Grotto Sites, Mogao Grottoes, Dunhuang, People's Republic of China, June 28-July 3, 2004. Los Angeles, CA: Getty Publications, 2010.

Alberro, Alexander. "A Messier Coherence: Inventing Abstraction at the Museum of Modern Art." Modernism/Modernity 20, no. 2 (June 27, 20I3): 37I-38I.

${ }_{55}$ Emma Stanford, "A Field Guide to Digital Surrogates: Evaluating and Contextualizing a Rapidly Changing Resource," in The Routledge Companion to Digital Humanities and Art History, ed. Kathryn Brown (New York: Routledge, 2020), 205. 
Baeza-Yates, Ricardo. "Bias on the Web." Communications of the ACM 6I, no. 6 (June 20I 8): 54 .

Baker, George, ed. “Artist Questionnaire: 2I Responses.” October Ioo (2002): 6-97.

Baumgärtel, Tilman. Net.art 2.0: New Materials Towards Net Art. Nuremberg: Verlag für Moderne Kunst, 200I.

Baumgärtel, Tilman. Net.art: Materialien zur Netzkunst. Nuremberg: Verlag für Moderne Kunst, I999.

Bogost, Ian. “The AI-Art Gold Rush Is Here.” The Atlantic, March 6, 20I9. https://www.theatlantic.com/technology/archive/20I9/o3/ai -created-art-invades-chelsea-gallery-scene/584 I34.

Bishop, Claire. "Against Digital Art History.” International Journal for Digital Art History, no. 3 (July 27, 2018): I 22-I3 I.

Bosma, Josephine. Nettitudes: Let's Talk Net Art. Amsterdam: Institute of Network Cultures, 20I I.

Brown, Kathryn, ed. The Routledge Companion to Digital Humanities and Art History. New York: Routledge, 2020.

Buchloh, Benjamin H. D., and Rachel Churner, eds. "Questionnaire: In What Ways Have Artists, Academics, and Cultural Institutions Responded to the U.S.-Led Invasion and Occupation of Iraq?" October I23 (2008): 3-I 84 .

Buck-Morss, Susan. "Visual Culture Questionnaire.” October 77 (I996): 29-3I.

Buck-Morss, Susan. "Visual Studies and Global Imagination.” Papers of Surrealism, no. 2 (2004).

Burdick, Anne, Johanna Drucker, Peter Lunenfeld, Todd Presner, and Jeffrey Schnapp. Digital_Humanities. Cambridge: MIT Press, 20 I 2.

Copeland, Huey, et al. "A Questionnaire on Decolonization.” October I74 (December I, 2020): 3-I25.

Dahlgren, Anna and Amanda Wasielewski. "The Digital U-Turn in Art History." Submitted.

Debatty, Régine. "Interview with Marisa Olson.” We Make Money Not Art (blog), March 28, 2008. http://we-make-money-not-art.com /how_does_one_become_marisa. 
Dickerman, Leah, Hal Foster, David Joselit, and Carrie Lambert-Beatty, eds. "A Questionnaire on Monuments." October I65 (August I, 2OI8): 3-I77.

“Digital Humanities Laboratory at Rutgers.” https://sites.google.com /site/digihumanlab/home.

Drucker, Johanna, and Claire Bishop. "A Conversation on Digital Art History.” In Debates in the Digital Humanities 2019. Minneapolis, MN: University of Minnesota Press, 20I9. https://dhdebates.gc .cuny.edu/read/untitled-f2acf7 2c-a469-49d8-be3 5-67f9acie3a6o /section/3aedfd2c-28of-4029-b3fI-3e9a I I 794co I\#ch27.

Drucker, Johanna, Anne Helmreich, Matthew Lincoln, and Francesca Rose. "Digital Art History: The American Scene." Perspective: Actualité en histoire de l'art, no. 2 (December 5, 20I 5).

Elgammal, Ahmed, Marian Mazzone, Bingchen Liu, Diana Kim, and Mohamed Elhoseiny. "The Shape of Art History in the Eyes of the Machine," January 23, 20I 8. http://arxiv.org/abs/I801.07729v2.

Ferguson, Andrew G. The Rise of Big Data Policing: Surveillance, Race, and the Future of Law Enforcement. New York: New York University Press, 2017.

Forensic Architecture. “Triple-Chaser: Forensic Architecture.” https:// forensic-architecture.org//investigation/triple-chaser.

Foster, Hal, ed. "Questionnaire on 'The Contemporary." October I30 (2009): 3-I 24 .

Garcia, Megan. "Racist in the Machine: The Disturbing Implications of Algorithmic Bias." World Policy Journal 33, no. 4 (2016): I I I-I I 7.

Getty Research Institute. "Provenance Index Databases." https:// www.getty.edu/research/tools/provenance/search.html.

Gold, Matthew K., ed. Debates in the Digital Humanities. Minneapolis, $\mathrm{MN}$ : University of Minnesota Press, $20 \mathrm{I} 2$.

“Information, n." In OED Online. Oxford University Press. http:// www.oed.com/view/Entry/95568.

Joselit, David, and Carrie Lambert-Beatty, eds. "[ I5 Responses to a Questionnaire on Occupy Wall Street].” October I42 (20I2): 26-73. 
Joselit, David, Carrie Lambert-Beatty, and Hal Foster, eds. "A Questionnaire on Materialisms." October I 55 (Winter 20I6): 3-I IO.

Kant, Immanuel. Critique of Judgement, edited by Nicholas Walker, translated by James Creed Meredith. Oxford: Oxford University Press, 2007.

Kester, Grant H. "Aesthetics after the End of Art: An Interview with Susan Buck-Morss.” Art Journal 56, no. I (I997): 38-45.

Klinke, Harald. "Big Image Data within the Big Picture of Art History," International Journal for Digital Art History, no. 2 (October I 8, 20I6): I4-37.

Kovacs, Claire L. "Mapping Paris: Social and Artistic Networks, I 85 5-I889." Leonardo 49, no. 5 (March 3I, 20I6): 446-446.

Liestøl, Gunnar, and Terje Rasmussen. "In the Presence of the Past: A Field Trial Evaluation of a Situated Simulation Design Reconstructing a Viking Burial Scene.” In Media Inspirations for Learning: Proceedings of EDEN 2010 , edited by A. Szucs and A. W. Tait. Budapest: Budapest University of Technology, 2010.

Manovich, Lev. "Data Science and Digital Art History." International Journal for Digital Art History, no. I (June 26, 20I 5): I 2-35.

Moretti, Franco. Distant Reading. London: Verso, 20I3.

“<nettime> Mailing List Archive." https://nettime.org.

Noble, Safiya Umoja. Algorithms of Oppression: How Search Engines Reinforce Racism. New York: New York University Press, 20 I 8.

“Questions of Feminism: 25 Responses.” October 7I (I995): 5-48.

Reside, Doug. "Last Modified January I996: The Digital History of RENT." Theatre Survey 52, no. 2 (November 20I I): 335-340.

Riley, Melanie A. Date Automated Detection of Prehistoric Conical Burial Mounds from LIDAR Bare-Earth Digital Elevation Models. Master's thesis, Northwest Missouri State University, 2009.

Ross, Nancy. "Teaching Twentieth Century Art History with Gender and Data Visualizations." The Journal of Interactive Technology and Pedagogy, no. 4 (December 2, 2013). 
Schreibman, Susan, Raymond George Siemens, and John Unsworth, eds. A Companion to Digital Humanities. Malden, MA: Blackwell Publishing, 2004.

Stallabrass, Julian. Internet Art: The Online Clash of Culture and Commerce. London: Tate Publishing, 2003.

Strezoski, Gjorgji, and Marcel Worring. "OmniArt: A Large-Scale Artistic Benchmark." ACM Transactions on Multimedia Computing, Communications, and Applications I4, no. 4 (October 23, 2018): 88:I-88:2I.

Terras, Melissa M., Julianne Nyhan, and Edward Vanhoutte, eds. Defining Digital Humanities: A Reader. London: Routledge, 2016.

Thylstrup, Nanna Bonde. The Politics of Mass Digitization. Cambridge: MIT Press, 2019.

Vierkant, Artie. “The Image Object Post-Internet.” Jstchillin (blog). 20IO. http://jstchillin.org/artie/pdf/The_Image_Object_Post-Internet _a4.pdf.

"Visual Culture Questionnaire." October 77 (I996): 25-70.

Whitelaw, Mitchell. "Representing Digital Collections.” In Performing Digital: Multiple Perspectives on a Living Archive, edited by David Carlin and Laurene Vaughan, 77-96. Farnham: Ashgate Publishing, 20I 5 .

Zhang, Shaozeng, Bo Zhao, and Jennifer Ventrella. "Towards an Archaeological-Ethnographic Approach to Big Data: Rethinking Data Veracity." Ethnographic Praxis in Industry Conference Proceedings 20I 8, I (20I8): 62-85.

Zweig, Ben. "Defining Digital Art History: What It Is, Is Not, and Should Be." Paper presented at the Digital Humanities Seminar, Uppsala University, September 25, 2019. 